\title{
STAT5B wt Allele
}

National Cancer Institute

\section{Source}

National Cancer Institute. STAT5B wt Allele. NCI Thesaurus. Code C52156.

Human STAT 5B wild-type allele is located in the vicinity of $17 q 11.2$ and is approximately

$77 \mathrm{~kb}$ in length. This allele, which encodes signal transducer and activator of transcription $5 B$ protein, is involved in cytokine and growth factor-mediated signal progression. In some acute promyelocytic leukemias, the wild-type allele is fused to the retinoic acid receptor-alpha allele. A homozygous missense mutation in this gene can result in Laron type dwarfism II. 